\title{
TEACHERS' NARRATIVES OF PEDAGOGICAL PRACTICES: TO EDUCATE FOR DEMOCRATIC PEACE IN EGYPT AND IN CANADA
}

\author{
Y. Awad \\ Post-doctoral Scholar CIDEC-OISE \\ University of Toronto, Canada \\ e-mail: yomna.awad@mail.utoronto.ca and yr@montessorileaders.ca
}

\section{ABSTRACT}

Education for democratic peacebuilding citizenship includes four essential components: handling conflict, practising dialogue, recognizing diversity, and building a pedagogical community. Teachers can help one another to interpret, to learn, and to implement these pedagogical practice dimensions, in order to equip their students with democratic agency and values to participate in peacebuilding social change. This comparative case study research examines how two groups of private school teachers - four in the Greater Cairo area and three in the Greater Toronto area voluntarily embarked on two journeys of non-formal professional learning to improve their teaching for democratic peace. The researcher developed and facilitated a six-session collaborative, reflective dialogic professional learning course for democratic peacebuilding, and studied each group of teachers' pedagogical practices.

Keywords: peacebuilding, conflict, democratic citizenship education, pedagogical practices, Egypt, Canada

\section{INTRODUCTION, PROBLEM STATEMENT AND RESEARCH OBJECTIVES}

An integral part of the peacebuilding process, during and after armed conflict, is to (re-)establish infrastructure to (re-)build healthy relationships and to nurture creative ideas and mutual understanding for social transformation (Maiese 2003; Lambourne 2004; Gill and Niens 2014). Teachers are the cornerstone of schooling, who can effectively assume roles to support social change (Ginsburg and Kamat 2009). Educators who are transformative intellectuals view their students (and themselves) as democratic agents, as they question processes of knowledge production, and engage in dialogue to enhance critical knowledge building for themselves and their students (Giroux and McLaren 1986). However, at present teachers themselves find scarce opportunities to engage in this very kind of authentic, active, dialogic teacher learning, to reflect on their practice and acknowledge the critical political role they may play in the future of any country (Bickmore 2005; Sprague 1992). 
Contemporary Egyptian society is suffering from torn relationships due to interpersonal and intergroup conflict. In addition, systemic conflict (Galtung 1969) problems of corruption and injustice are plaguing the country. Canada, although ostensibly a more peaceful and democratic country, has its own conflicts of discrimination and human rights violations especially visibly against aboriginal people-disguised under the notion of multiculturalism (Thobani 2007). There has been varying emphasis on research pertaining to democratic peacebuilding citizenship in the field of comparative education. Hahn (2016) pinpoints the need for empirical research that speaks to the implemented curriculum in the classroom. Although there has been a considerable amount of research examining the effects of the received curriculum on students' learning, for example the international large-scale IEA studies, and researchers interviewing students to identify the emphasis of the received curriculum, there is little research on both the pedagogy and implemented curriculum. Furthermore, Hahn (2010; 2016) speaks of the need of comparative research that is culturally relevant and context-specific since most of the research presented in pedagogy is rooted in Anglo-American settings and/or ideology. Therefore, I have done this study, through the lens of a transnational citizen, to examine how teachers in two contrasting contexts might be supported to develop and implement democratic peacebuilding citizenship education. The goal was to learn from this experience of peacebuilding citizenship education: (a) what the teacher participants said they understood and taught in their own classrooms, and (b) how this online dialogue-centred course facilitated their professional learning. This paper focuses on teachers' reported narratives of the implemented curriculum and answers the following research question: How did selected small groups of teachers in an Egyptian and a Canadian context teach and facilitate peacebuilding and citizenship education?

\section{THEORETICAL FRAMEWORK}

Democratic peacebuilding citizenship education reflects a broad set of complex transformative pedagogical goals. The notions of democracy and citizenship are multi-faceted (Awad 2019). They have various conceptions in different global contexts that shape how educators teach for democratic peacebuilding citizenship in post-conflict zones, societies transiting out of conflict and relatively democratic societies. Its vital components arise, among other places, in theories of education for humanization, human rights education, culturally relevant pedagogy or pedagogy of hope. One can derive four essential components of democratic peacebuilding education that occur in each of them: (1) addressing and handling conflict, (2) practicing dialogue, (3) recognizing (including and humanizing) diversity and (4) building pedagogical community. I argue that, together, these educational components may promote agency for democratic decision making, humanizing values, and other capacities to mobilize social change. 


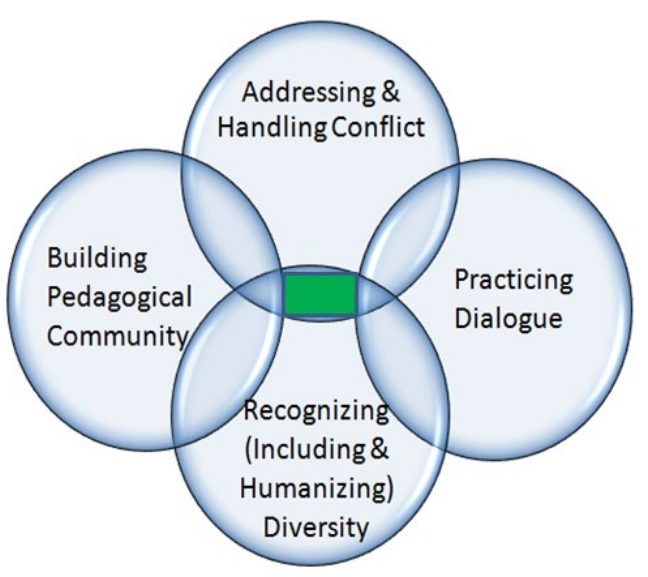

Figure 1: Components of democratic peacebuilding citizenship education

Figure 1 depicts these four intersecting components of education for democratic peacebuilding citizenship. Democratic peacebuilding citizenship education occurs at the intersection of these four components (the green shaded area): handling conflict, practicing dialogue, recognizing diversity and building a pedagogical community (Awad 2019).

Conflict as natural and uncomfortable (not necessarily destructive) as is (Lederach 2003/2005; Bickmore 2008), provides opportunities for students to unravel the actors and actions involved in a conflict, unveil underlying causes of conflict (including structural root causes) to enable students to delve into the hegemonic structures of power in society (Apple 1979/2004; Davies 2005), discuss conflictual issues (Bickmore 2012; Hess and Avery 2008; King 2009; Johnson and Johnson 2009) (including political and historical conflicts) to foster students' abilities to see the other perspectives in the conflict, listen to a different narrative and sometimes take a stance (Davies 2014), and finally to use conflict as a transformational force to promote social change (Lederach 2006; Bickmore 2014). Dialogue for democratic peacebuilding citizenship is different than mere communication. Dialogue is used as a peacemaking mechanism in schools (Bickmore 2011; Bickmore and Parker 2014) through the implementation of certain strategies including peer mediation (Jones 2004; Harris 2005), restorative justice conferencing and peace circles (Vaandering 2014). As a peacebuilding mechanism, intergroup dialogue across differences is geared towards bringing cross-ethnic encounters among students to elicit various perspectives and narratives and in some instances give students from marginalized minorities a voice (Nagda and Gurin 2007). Dialogue with its peacemaking and peacebuilding mechanisms can promote positive peace beyond the absence of conflict through the cultivation of students' conflict resolution skills, humanizing and (re-)building relationships and possibly promoting social collective action - e.g. awareness 
campaigns (Bickmore 2014; 2015).

Recognizing diversity in terms of inclusion and humanization is the third essential component to educate for democratic peacebuilding citizenship. Diversity is manifested in various trajectories, ethnic, racial, religious, cultural, political and even in terms of abilities. Teaching students inclusion and acceptance of differences is a key ingredient in promoting peacebuilding citizenship. Culturally relevant pedagogy is one approach educators may use to acknowledge differences and unveil the richness and value of diversity (Ladson-Billing 1995; 2014). The fourth critical component is building a pedagogical community in the sense of nurturing a sense of trust, safety and belongingness (Feinberg 2006; Smith 2008; Wong et al. 2013), while encouraging students to practice peacemaking and peacebuilding dialogic mechanisms to develop their participatory and civic engagement skills (Campbell 2008; Levy, Solomon and Collet-Gildard 2016; Levy, Collet-Gildard and Owenby 2017).

\section{METHODS AND DATA SOURCES}

Enlightened by the review of the literature, I developed a six-session online course to incorporate the four components in my conceptual framework for democratic peacebuilding citizenship education: addressing and handling conflict, practicing dialogue, recognizing diversity and building a pedagogical community. To achieve the goals of this study, I employed qualitative practice-based participatory methods in the course and research design. In the course design, teachers provided their input by expressing their expectations and learning needs. Although I designed and facilitated the course, teachers' dialogues helped to shape it. Further, teacher participants developed lessons for their own classrooms during the course, and some voluntarily tried and shared those pedagogical moments with course participant colleagues.

Upon obtaining approval from the Research Ethics Board, I piloted the course with two groups of teachers in private suburban elementary school settings in different national contexts. Teacher participants were a convenience sample of volunteers in each city, outside of their school work context four from three international private schools in the Greater Cairo area and three from one private school (with a religious designation) in the Greater Toronto area. I facilitated a six-session online course with each group of teachers, introducing and enacting (co-adapting to each context with teacher participants) collaborative and dialogic professional learning. I recruited participants who taught language, science, math or social studies for grades 3-9. Participating teachers in Egypt were: Jayda, Sally, Mountain and John (a Canadian teaching in Egypt). Participating teachers in Canada were: Tupi, Shelly and Sandy.

The data sources, collected via the online platform that hosted the six-session course processes, were: asynchronous discussion threads, messages and reflective notes in each context. The online platforms (one in each context) included the discussion threads linked to 
the course readings, responses to tasks, along with teachers' interactions and comments on posts. Thus, the activities on the online platform provided data on teachers' understandings of each component of democratic peacebuilding citizenship (handling conflict, practicing dialogue, recognizing diversity and building a pedagogical community) as these understandings unfolded during the discussion throughout the sessions and in participants' narratives of practice (about their actual teaching for democratic peacebuilding citizenship in their classrooms). Data were collected over the course of 6 months (much longer than the originally planned 6-10 weeks) in each context, and thematic data analysis took 8 months to help answer the research questions.

\section{RESULTS AND/OR SUBSTANTIATED CONCLUSIONS}

While teachers presented somewhat similar pedagogical practices and teaching strategies in both contexts, the types of conflicts handled varied from one context to the other. In Egypt, a relatively authoritarian society, teachers focused more on addressing conflicts related to human rights, equity and acceptance of differences, this is in contrast to the Canadian teaching in Egypt, who intentionally addressed 1973 war with Israel and the American Civil war. Participating teachers in Canada chose to discuss one identity issue with which they all particularly identified from the viewpoint of Muslim minoritized community in Canada Islamophobia - whereas the rest of the conflicts addressed were wider-scale current issues such as the Syrian war and Syrian refugee crisis, and colonialism. To address conflicts, participating teachers in both contexts used various teaching strategies that involved constructive communication, dialogue and deliberation. Hence, communication and dialogue played a vital role as part of peacemaking and peacebuilding mechanisms in those teachers' classrooms. Teachers encouraged verbal and non-verbal communication and stressed on the importance of having students listen to various perspectives before formulating their own opinions on issues.

All seven teachers stated that they used debates to expose students to multiple and sometimes contrasting perspectives (peacemaking approach). They would also discuss various conflictual issues and brainstorm possible solutions with their students. They emphasized collaborative activities to build relationships in their classrooms. Using literature to address a specific conflict - for example, hatred - was a peacebuilding approach reported by teachers in both contexts. Teachers maintained the use of story books was a powerful approach to teaching students about conflictual issues since students usually connect with the characters and can develop empathy.

The striking difference between the understandings of these two groups of teachers was in the ways they took up the concept of recognizing (including and humanizing) diversity. Diversity was considered a given in the Canadian context: it is a multicultural society, 
Canadians are used to differences, and living together is what they strive to do, so democratic peacebuilding citizenship education can help promote this rhetoric and achieve these goals. In the narratives and teaching examples of the Egyptian teachers, one can see and feel that the notion of valuing diversity is a struggle, in spite of the fact that these privileged Egyptians are used to seeing and dealing with foreigners who visit and live in Egypt. Perhaps the 2013 armed conflict that ripped the social fabric of the country made dealing with differences of opinion a conflict, let alone dealing with diversity in its ideological sense, meaning various identities, including socio, economic, political, and religious and gender differences. Diversity is not assumed within the Egyptian identity, as was the case with the selected Canadian teachers, and this struggle was evident all along their discussions in this course.

In sum, teachers' narratives of practice in both contexts support the inclusion of the four components of democratic peacebuilding citizenship education, along with student-centred pedagogical practices to foster their students' sense of agency. Table 1 sums up participating teachers' teaching practices in Egypt and in Canada.

Table 1: Cross-case: Teacher participants' pedagogical practices for teaching democratic peacebuilding citizenship

\begin{tabular}{|c|c|c|c|c|c|c|c|}
\hline & Jayda & Sally & Mountain & John & Tupi & Shelly & Sandy \\
\hline $\begin{array}{l}\text { Handling interpersonal conflicts through } \\
\text { peacekeeping }\end{array}$ & & & $\mathrm{X}$ & & $\mathrm{X}$ & $\mathrm{X}$ & $\mathrm{X}$ \\
\hline $\begin{array}{l}\text { Handling interpersonal conflict through } \\
\text { peacemaking (discussion) }\end{array}$ & $\mathrm{X}$ & $\mathrm{X}$ & $\mathrm{X}$ & $\bar{X}$ & $\mathrm{X}$ & $\mathrm{X}$ & $\mathrm{X}$ \\
\hline $\begin{array}{l}\text { Using songs to calm students involved } \\
\text { in a conflict }\end{array}$ & & & & & & & $\mathrm{X}$ \\
\hline Using songs to build community & & & $\bar{X}$ & & & $\mathrm{X}$ & \\
\hline Using Think-Pair and Share & $\mathrm{X}$ & & & & $\mathrm{X}$ & & \\
\hline $\begin{array}{l}\text { Using children's literature and stories to } \\
\text { address conflicts }\end{array}$ & $\bar{X}$ & $\mathrm{X}$ & $\bar{X}$ & $\bar{X}$ & $\bar{X}$ & $\mathrm{X}$ & $\mathrm{X}$ \\
\hline $\begin{array}{l}\text { Using visuals to show good and bad } \\
\text { choices and behavioural consequences }\end{array}$ & & & & & & & $\mathrm{X}$ \\
\hline $\begin{array}{l}\text { Using Current events to flag and } \\
\text { discuss current conflicts }\end{array}$ & $\mathrm{X}$ & & & $\mathrm{X}$ & $\mathrm{X}$ & $\mathrm{X}$ & \\
\hline Journal Writing for Reflection & $\mathrm{X}$ & & & $\mathrm{X}$ & $\bar{x}$ & $\mathrm{X}$ & \\
\hline Addressing historical conflicts & & & $\mathrm{X}$ & $\mathrm{X}$ & & $\mathrm{X}$ & \\
\hline $\begin{array}{l}\text { Presenting morals and values } \\
\text { (including religious themes) }\end{array}$ & $\bar{X}$ & $\mathrm{X}$ & & & $\mathrm{X}$ & $\mathrm{X}$ & $\mathrm{X}$ \\
\hline Implementing character education & $\mathrm{X}$ & $\mathrm{X}$ & & & $\mathrm{X}$ & $\mathrm{X}$ & $\mathrm{X}$ \\
\hline Using peace/restorative circles & $\mathrm{X}$ & & & & $\mathrm{X}$ & & $\mathrm{X}$ \\
\hline Implementing peer mediation & $\mathrm{X}$ & & & & & $\mathrm{X}$ & $\mathrm{X}$ \\
\hline $\begin{array}{l}\text { Conducting debates to scrutinize and } \\
\text { challenge students' thinking }\end{array}$ & $\mathrm{X}$ & $\mathrm{X}$ & & & $\mathrm{X}$ & $\mathrm{X}$ & \\
\hline Using Four-Corners Debate & $\mathrm{X}$ & & & & & $\mathrm{X}$ & \\
\hline $\begin{array}{l}\text { Discussing various conflictual topics } \\
\text { and brainstorming possible solutions }\end{array}$ & $\mathrm{X}$ & $\mathrm{X}$ & $\mathrm{X}$ & $\mathrm{X}$ & $\mathrm{X}$ & $\mathrm{X}$ & $\mathrm{X}$ \\
\hline Drafting classroom rules & & & & $\mathrm{X}$ & $\mathrm{X}$ & & \\
\hline Collaborative group activities & $\mathrm{X}$ & $\mathrm{X}$ & $\mathrm{X}$ & $\mathrm{X}$ & $\mathrm{X}$ & $\mathrm{X}$ & $\mathrm{X}$ \\
\hline $\begin{array}{l}\text { Using role playing to model conflict } \\
\text { scenarios }\end{array}$ & $\mathrm{X}$ & & $\mathrm{X}$ & & $\mathrm{X}$ & $\mathrm{X}$ & $\mathrm{X}$ \\
\hline Discussing ethical dilemmas & & $\mathrm{X}$ & & & & & \\
\hline
\end{tabular}




\begin{tabular}{|l|c|c|c|c|c|c|c|}
\hline & Jayda & Sally & Mountain & John & Tupi & Shelly & Sandy \\
\hline $\begin{array}{l}\text { Presenting influential talks and videos } \\
\text { to promote peace }\end{array}$ & $\mathrm{X}$ & $\mathrm{X}$ & $\mathrm{X}$ & $\mathrm{X}$ & & & \\
\hline $\begin{array}{l}\text { School-wide advisory program and } \\
\text { adult guidance }\end{array}$ & $\mathrm{X}$ & $\mathrm{X}$ & & & & & \\
\hline $\begin{array}{l}\text { Research and use of student-chosen } \\
\text { stereotypes }\end{array}$ & $\mathrm{X}$ & & & & & & \\
\hline
\end{tabular}

\section{SCHOLARLY SIGNIFICANCE OF THE STUDY}

The significance of this study is two-fold: it is educational research that explores how two small groups of teachers, one in the global South and one in the global North educate for democratic peace, as well as an instance of teacher professional learning that is responsive to each teacher learning group context. Thus, this research provides a real on-the-ground example of teacher professional learning that includes the voices of teachers who have experienced armed conflict, transnational migration and/or social exclusion. It also explores two small groups of teachers' pedagogical practices through eliciting reflections on their own classroom teaching and in turn on their students' own contexts affected by armed conflict, globalization, and/or social exclusion. Hence, this study probes the meanings and key components of peacebuilding citizenship education in actual elementary teachers' narratives and teaching contexts. However, those pedagogical practices could be adopted in higher education settings in various contexts: post-conflict zones, societies transitioning out of violent conflict, or relatively democratic society to teach students essential peacemaking and peacebuilding skills that are indispensible for democratic peacebuilding citizenship education.

\section{REFERENCES}

Apple, M. 1979/2004. Ideology and curriculum. In The hidden curriculum and the nature of conflict (Chapter 5), 77-97. New York: Routledge.

Awad, Y. R. 2019. Food for thought: The trajectories of democratic peace-building citizenship education. Citizenship Teaching \& Learning 14(3): 347-363.

Bickmore, K. 2005. Teacher development for conflict participation: Facilitating learning for "difficult citizenship" education. International Journal of Citizenship and Teacher Education 1(2): 2-14.

Bickmore, K. 2008. Education for conflict resolution and peacebuilding in plural societies: Approaches from around the world. In Comparative and international education: Issues for teachers, ed. Karen Mundy, Kathy Bickmore, Ruth Hayhoe, Katherine Madjidi and Meggan Madden, 249-272. Toronto and New York: Canadian Scholars Press and Teachers College Press.

Bickmore, K. 2011. Keeping, making and building peace in school. Social Education 75(1): 40-44.

Bickmore, K. 2012. Peacebuilding dialogue as democratic education: Conflictual issues, restorative problem-solving, and student diversity in classrooms. In Debates in citizenship education, ed. James Arthur and Hilary Cremin, 115-131. Routledge.

Bickmore, K. 2014. Peace-building dialogue pedagogies in Canadian classrooms. Curriculum Inquiry 44(4 September): 553-582.

Bickmore, K. and C. Parker. 2014. Constructive conflict talk in classrooms: Divergent approaches to addressing divergent perspectives. Theory and Research in Social Education 42(4): 291-335.

Bickmore, K. 2015. Incorporating peace-building citizenship dialogue in classroom curricula: 
Contrasting cases of Canadian teacher development. In Building democracy in education on diversity, ed. Régis Malet and Suzanne Majhanovich, 17-39. Rotterdam, Netherlands: Sense Publishers.

Campbell, D. E. 2008. Voice in the classroom: How open classroom climate fosters political engagement among adolescents. Political Behavior 30(4): 432-454.

Davies, L. 2005. Teaching about conflict through citizenship education. International Journal of Citizenship and Teacher Education 1(2): 17-34.

Davies, L. 2014. Interrupting extremism by creating educative turbulence. Curriculum Inquiry 44(4).

Feinberg, W. 2006. For goodness sake: Religious schools and education for democratic citizenry (Social theory, education and cultural change). New York, NY: Routledge.

Galtung, J. 1969. Violence, peace, and peace research. Journal of Peace Research 6(3): 167-191.

Gill, S. and U. Niens. 2014. Education as humanisation: A theoretical review on the role of dialogic pedagogy in peacebuilding education. Compare: A Journal of Comparative and International Education 44(1): 10-31.

Ginsburg, M. B. and S. Kamat. 2009. The orientations of teachers. In International handbook of research on teachers and teaching, Volume 21, ed. Saha J. Lawrence and A. Gary Dworkin, 231-241. Springer International Handbooks of Education.

Giroux, H. A. and P. McLaren. 1986. Teacher education and the politics of engagement: The case for democratic schooling. Harvard Educational Review 56(3): 213-239.

Hahn, C. 2010. Comparative civic education research: What we know and what we need to know. Citizenship Teaching and Learning 6(1): 5-23.

Hahn, C. 2016. Pedagogy in citizenship education research: A comparative perspective. Citizenship Teaching \& Learning 11(2): 121-137.

Harris, R. 2005. Unlocking the learning potential in peer mediation: An evaluation of peer mediator modeling and disputant learning. Conflict Resolution Quarterly 23(2): 141-164.

Hess, D. and P. Avery. 2008. Discussion of controversial issues as a form and goal of democratic education. In Sage handbook of education for citizenship and democracy, ed. J. Arthur, I. Davies and C. Hahn, 506-518.

Johnson, D. and R. Johnson. 2009. Energizing learning: The instructional power of conflict. Educational Researcher 38(1, January): 37-51.

Jones, T. S. 2004. Conflict resolution education: The field, the findings, and the future. Conflict Resolution Quarterly 22(1-2): 233-267.

King, J. 2009. Teaching and learning about controversial issues: Lessons from Northern Ireland. Theory \& Research in Social Education 37(2): 215-246.

Ladson-Billings, G. 1995. But that is just good teaching! The case for culturally relevant pedagogy. Theory into Practice 34(3): 159-165.

Ladson-Billings, G. 2014. Culturally relevant pedagogy 2.0: a.k.a The Remix. Harvard Educational Review 84(1): 74-83.

Lambourne, W. 2004. Post-conflict peacebuilding: Meeting human needs for justice and reconciliation. Peace, Conflict and Development (4): 1-24.

Lederach, J. P. 2003/2005. Conflict transformation. In Beyond intractability, ed. Guy Burgess and Heidi Burgess. Conflict Research Consortium, University of Colorado, Boulder, Colorado, USA. http://www.beyondintractability.org/essay/transformation/

Lederach, J. P. 2006. Defining conflict transformation. Peacework 33(368): 26-27.

Levy, B. L. M., B. G. Solomon and L. Collet-Gildard. 2016. Fostering political interest among youth during the 2012 presidential election: Instructional opportunities and challenges in a swing state. Educational Researcher 45(9): 483-495.

Levy, B. L. M., L. Collet-Gildard and T. C. Owenby. 2017. Generating dynamic democratic discussions: An analysis of teaching with U.S. presidential debates. The Social Studies 108(2): 39-54. 
Maiese, M. 2003. Peacebuilding. Beyond intractability, ed. Guy Burgess and Heidi Burgess. Conflict Information Consortium, University of Colorado, Boulder. http://www.beyondintractability.org/ essay/peacebuilding

Nagda, B. R. A. and P. Gurin. 2007. Intergroup dialogue: A critical-dialogue approach to learning about difference, inequality, and social justice. New Directions for Teaching and Learning 2007(111): $35-45$.

Smith, O. R. 2008. The paradox of trust in online collaborative groups. Distance Education 29(3): 325340.

Sprague, J. 1992. Critical perspectives on teacher empowerment. Communication Education 41(2): 181203.

Thobani, S. 2007. Exalted subjects: Studies in the making of race and nation in Canada. Toronto: University of Toronto Press.

Vaandering, D. 2014. Relational restorative justice pedagogy in educator professional development. Curriculum Inquiry 44(4).

Wong, K., R. Remin, R. Love, R. Aldred, P. Ralph and C. Cook. 2013. Building pedagogical community in the classroom. Christian Higher Education 12(4): 282-295. 